\title{
Lumen
}

Selected Proceedings from the Canadian Society for Eighteenth-Century Studies

\section{A Survey of Recent Scholarship in English by CSECS Members}

\section{Mark McDayter et Lisa M. Zeitz}

Volume 25, 2006

URI : https://id.erudit.org/iderudit/1012088ar

DOI : https://doi.org/10.7202/1012088ar

Aller au sommaire du numéro

Éditeur(s)

Canadian Society for Eighteenth-Century Studies / Société canadienne d'étude du dix-huitième siècle

ISSN

1209-3696 (imprimé)

1927-8284 (numérique)

Découvrir la revue

Citer ce compte rendu

McDayter, M. \& Zeitz, L. M. (2006). Compte rendu de [A Survey of Recent Scholarship in English by CSECS Members]. Lumen, 25, 233-244.

https://doi.org/10.7202/1012088ar

Copyright (c) Canadian Society for Eighteenth-Century Studies / Sociéte canadienne d'étude du dix-huitième siècle, 2006
Ce document est protégé par la loi sur le droit d'auteur. L'utilisation des services d'Érudit (y compris la reproduction) est assujettie à sa politique d'utilisation que vous pouvez consulter en ligne.

https://apropos.erudit.org/fr/usagers/politique-dutilisation/ 


\section{Review Articles / Recencement des recherches}

\section{A. A Survey of Recent Scholarship in English by CSECS Members}

2004 was a fruitful year for eighteenth-century scholarship in Canada, as even a casual perusal of the output of our specialists in the period will make apparent. The work of Canadian scholars upon the literature, culture, and history of the period covers an impressively wide expanse of subject matter, and includes scholarly editions, biographies, thematic studies, catalogues, collections of critical essays and primary sources, and monographs on individual authors. The brief survey that follows cannot pretend to comprehensiveness, but it does provide an illuminating glimpse of the range and accomplishment of our nation's contributions to eighteenth-century studies over the course of a single year. There is much here that will edify, instruct, and enlighten, but, even more gratifyingly, it has been the experience of these reviewers that there is also a great deal to savour and enjoy.

$$
* * *
$$

Perhaps the greatest compliment a reader can pay to a scholar is to say that, as a result of reading a critical study, one is compelled to re-read and to re-consider its subject. Such a compliment must be paid to Nicholas Hudson and his wide-ranging and provocative Samuel Johnson and the Making of Modern England (Cambridge: Cambridge University Press, 2003). This is a major book on a major author that engages some of the most important current concerns in eighteenth-century studies, and argues that Johnson is a 'far more complex, significant, and even forward-looking figure than historians have generally acknowledged' (12). Hudson's tone throughout his study is corrective. Sharing Johnson's 'spirit of contradiction' (a spirit that makes his study so stimulating), Hudson opposes the tendency he discerns in some current scholarship to 'tailor intellectual history to our own ideological agendas' and attempts, instead, to read Johnson within his eighteenth-century social and cultural contexts - 'as part of a process that was changing 
England from a pre-modern into a modern society' (2). Johnson is neither as compellingly conservative nor as pleasingly progressive as some would have him; his was the perspective of an upwardly mobile figure of the 'incipient' middle class which saw that its interests would be best served by a traditional, but flexible, social order. Through both a careful examination of controversies within Johnson scholarship and criticism, and fresh readings of primary texts, Hudson offers balanced and nuanced accounts of eighteenth-century party politics and Johnson's political writings (the 'modernity' of which Hudson claims, knowing his views will be controversial); Johnson's open-mindedness on feminist issues and his promotion of education for women, something that Hudson characterizes as part of a larger 'project of middle-rank consolidation' (75); and Johnson's contribution to the 'construction of English nationhood' - with its attendant negotiations between public spirit and private self-interest, and its promise of emerging greatness and prosperity - and the place of empire in that conception (here Hudson weighs Johnson's support of a 'moral' empire over a mercantile one, and warns that Johnson was more supportive of the promise of empire - especially its potential to promote Christian 'civilization' and 'the peace of nations' - than some scholars would have him). Hudson's book, then, in its own re-making of our understanding of 'Samuel Johnson' simultaneously explores not only how Johnson 'was made by the evolving social circumstances of his age but also how he helped to construct the meaning of what it was to be "English"' (5).

Another study that engages the making of the middle class in England - specifically, the formation of a new subject category in late-eighteenth-century England - is Andrew O'Malley's The Making of the Modern Child: Children's Literature and Childhood in the Late Eighteenth Century (New York: Routledge, 2003), Number 28 in Routledge's 'Children's Literature and Culture' series. A fundamentally middle-class construction, the product of 'an emerging, oppositional middle-class ideology' (3), the modern child (as represented in the pedagogical, medical, and children's literatures of the period) embodied the virtues (industry, obedience, self-reliance) and exhibited the social practices (charity, thrift) upon which industrial capitalism would come to depend. Indeed, the author argues, these literatures 'helped create that very system' (16). O'Malley's work is very well informed by previous scholarship on early children's literature (which is engaged deftly and critically by the author), but where this book stands apart is in its careful distinctions of class difference and its focus on the middle classes as 'the primary source of the ideological content of children's literature in its early years' (20). Working in the line of Raymond Williams and E. P. Thompson, $\mathrm{O}^{\prime}$ Malley displays an acute awareness of the importance of class dynamics. His 
exploration of the self-representation of the middle class as moral, productive, and different from the classes above and below, and his emphasis on children's literature as a mechanism of control, discipline, and the internalization and normalization of middle-class values result in a study that is as much about the cultural production of class and the making of a middle-class British identity as it is about children's literature. Still, it is through fine close readings of familiar primary texts that O'Malley makes his argument, and those looking for fresh and astute discussions of authors like Trimmer, Day, the Kilners, and Wakefield, and works such as Little Goody Two-Shoes will not be disappointed.

Sarah Fielding wrote for children, too, but was best known in her own age, as in ours, as 'the author of David Simple' (published in 1744), and sister to Henry Fielding. Perceptions change, however, and Peter Sabor's new Broadview edition of The History of Ophelia (Peterborough: Broadview Press, 2004), Fielding's last novel, provides a new reason to reacquaint ourselves with this increasingly important novelist who, as Sabor notes, seems 'set to become widely read and vigorously debated once again' (30). There is, in fact, much in this newly edited novel to spark such debate. Published in 1760, The History of Ophelia is an epistolary comic narrative featuring a fascinating blend of influences and styles. It employs a parodic gothic setting, four years (as Sabor points out in his introduction) before the publication of The Castle of Otranto. Somewhat unusually for the period, Fielding employs an idyllic pastoral Welsh setting for the first portion of her narrative, and uses Ophelia's ignorance of English culture and 'civilization' as the vehicle for much gentle satire. Above all, however, The History of Ophelia can be read as a sympathetically revisionist retelling of Samuel Richardson's Clarissa. In place of the attractive but ultimately irredeemable Lovelace, Fielding gives us Lord Dorchester, an abductor who, despite his libertine beginnings, becomes the protector rather than the ravisher of Ophelia. In so doing, Fielding acts upon the notion, expressed in her 1749 Remarks on Clarissa, that one can imagine Richardson's heroine with 'a Lover whose honest Heart, assimulating (sic) with hers, would have given her leave, as she herself wishes, to have shewn the Frankness of her Disposition, and to have openly avowed her Love' (299).

Peter Sabor's treatment of his text has resulted in an exemplary teaching edition, and one that fits well with the other excellent classroom texts for which Broadview has become well-known. The History of Ophelia is an old-spelling edition, but the text has been well annotated, so that there is little here likely to give undergraduates much difficulty. In a succinct but invaluable (and fully-referenced) introduction of some thirty pages in length, Sabor provides an informative outline of Fielding's writing career, and locates the novel itself within a variety of 
different contexts, carefully tracing its influences and parallels (as for example with Charlotte Lennox's The Female Quixote). As is usual with Broadview editions, The History of Ophelia includes appendices that feature excerpts from a number of contemporary and near-contemporary materials. In addition to the useful excerpt from Fielding's Remarks on Clarissa, quoted above, the edition includes three contemporary reviews, the text of a spurious addition to the Dublin edition of 1763, and three illustrations from a 1785 reprinting of the novel. Also, in the interest of locating the text within a larger literary context, Sabor has added an excerpt from Letters Written by a Peruvian Princess (1748), a novel which may have provided a model for Fielding, and from Frances Burney's Evelina, a passage that may, in turn, have been influenced by Fielding's novel. If it is true that the discipline is ripe for a resuscitation of Sarah Fielding's works, Sabor has provided an edition that will do much to facilitate it.

Much of the impetus for recent reappraisals of previously neglected authors such as Sarah Fielding, of course, has derived from the vibrant and exciting fields of gender and sexuality studies. Raymond Stephanson's The Yard of Wit: Male Creativity and Sexuality, 1650-1750 (Philadelphia: University of Pennsylvania Press, 2004) is an engaging and thorough study of the 'culture of eighteenth-century male creativity' as revealed through its employment of images of the male genitalia. The degree to which Stephanson is breaking new ground here is evident from the anecdotes he recounts in his frequently amusing Preface, in which he places the inception of this study within the context of an academic culture that had not yet developed a place for its subject matter and approach. That one of his colleagues apparently assumed a paper he was delivering on the subject of 'Men \& "Yard"-Work in the Seventeenth and Eighteenth Centuries' was to be about men's domestic labour highlights the degree to which even the vocabulary for discussions of masculine sexuality in the period remains new and unfamiliar, despite the recent rise of the field of 'male studies.'

Stephanson's interest is in the shift in the perceptions and understanding of masculinity in the eighteenth century, and, in particular, with the way in which these changing paradigms are reflected in the period's characterization of male creativity. As he notes, the 'male literary culture of the period depended on a shared symbolic and metaphorical system to fashion a myth about its own creativity.' The range of expressions of this myth is, of course, enormous, and Stephanson's discussion provides copious examples. The result is, however, far more than a catalogue of conventionalized metaphors for masculine creativity, for the author places all within the contexts of the 'hierarchical dynamics and power structures of male literary communities' (xii), and of the 
concurrent and related shifts in the cultural perceptions of the 'literary,' and of the literary marketplace in particular.

Stephanson's central focus in this study is Pope, as the writer who most clearly associated his own creative power with his sexuality, and who was most notoriously victimized by public attacks upon his putative sexual inadequacies. But the book's explorations of the context and background for the association of male creativity with masculine sexuality range far beyond the subject of 'Alexander the Little': Rochester, Wycherley, Sterne, and Wortley Montagu, to name but a few, receive significant attention here as well. Working its way authoritatively through such fields of study as diverse as eighteenth-century medicine and physiology, the literary trade, and social and cultural history, The Yard of Wit weaves a compelling and convincing portrait of its subject that is bound to prove an important contribution to our understanding of gender and literary creativity in the period.

Juliet McMaster is probably best known for her work on Jane Austen and nineteenth-century fiction, but in Reading the Body in the EighteenthCentury Novel (Houndmills; New York: Palgrave Macmillan, 2004) she has produced a fascinating study of the use and significance of nonverbal communication in the eighteenth century that will be of interest to almost anyone working in the earlier period. Although McMaster suggests that her book is less 'a history of ideas' than a 'study of the assimilation of ideas' (xii), her study is comprehensive and wide-ranging enough to provide a solid introduction to what is a surprisingly large and complicated subject. She is centrally concerned with the novel, and her focus is, in particular, upon such works as Tristram Shandy, Tom Jones, Clarissa, Sir Charles Grandison, and Camilla, but her treatment of the intellectual and artistic contexts through which these novels can be read takes her much further afield than might be expected from a simple 'literary' study.

For McMaster, the 'reading' of body language in the eighteenth century was less the unconscious reflex that it has become today than a very deliberate exercise in communication. Physiognomy and its related fields were, for that reason, also a subject of very serious debate in the period, 'congenial to the physician, the physiognomist, the painter, the actor, and the novelist' (xiii). While we arguably share with the eighteenth century a yearning for the ability to read the mind through the body, for trustworthy correspondences between exterior and interior, such debates played a more important role then than they do now. Indeed, McMaster argues that some eighteenth-century novels were participants in these disputes about the validity of the emotional and psychological evidence provided by the body. 
The variety suggested by the catalogue of professions interested in physiognomy, quoted above, gives a good indication of the scope of McMaster's exploration of her subject. She usefully looks (as did eighteenth-century authorities) to visual artists like Hogarth and Le Brun for cues, as well as to theatrical representations of emotion. There is also a most useful discussion of medical models, and of scientific/philosophical approaches to the body and communication, including an examination of the roots of these ideas in classical sources such as Aristotle's Physiognomonica. McMaster eschews a simple chronological arrangement of her materials in favour of a thematic structure, as she deals in turn with some of the different 'codes' used to read the body. This organizational principle allows each chapter to, in some sense, run in parallel with the others, a method that makes the correspondences between the variety of different approaches to nonverbal communication all the more evident. Reading the Body deals in some depth with the fields of medicine (with reference to Tristram Shandy), physiognomy, facial expression (with a focus upon Le Brun and Richardson's Clarissa), and gesture (discussed in the context of the theatre and Frances Burney's Camilla). A conclusion that looks ahead through Jane Austen to the nineteenth century makes it clear that, whatever the fate of such systematized approaches to nonverbal communication as physiognomy, later ages were no less anxious to read the mind through varieties of bodily display.

Between 1987 and 2003, the International Society for Eighteenth Century Studies hosted a series of five separate round-tables on the subject of the life, works, and influence of William Beckford. Held in five different countries on two continents, the meetings have borne fruit with the publication of an essay collection entitled William Beckford and the New Millennium (New York: AMS Press, 2004), edited by Kenneth W. Graham with Kevin Berland. The geographical range of the sites of the round-tables that were the genesis for this volume (Number 47 of AMS Studies in the Eighteenth Century) is reflected in the international origins of the contributors, who hail from Italy, France, Sweden, Portugal, Brazil, the United Kingdom, Canada, and the United States, a fact that is not inappropriate given that, as the editors note, Beckford himself 'was a sensitive traveller able to discover and convey sympathies throughout Europe' (1).

The introduction to the collection cites three recent events that have prompted a reassessment of Beckford entering into the new millennium: a New York and London exhibition of works from Beckford's collections of object d'arts, a 'paradigm shift' in studies of gender that has 'been extending sympathetic understandings of gay and lesbian sexualities in the eighteenth and nineteenth centuries' (2), and the new accessibility of 
a collection of Beckford manuscripts left as a bequest to the Bodleian Library. All of these are reflected, to lesser or greater degrees, in a volume that exhibits enormous diversity in its subject matter and approaches: the thirteen essays to be found herein approach their versatile author through the visual arts, music, literature, sexuality, landscape and interior design.

The essays have been arranged to reflect the 'stages of Beckford's creative life' (3): the first three, by John Benyon, Mirella Billi, and Dick Claésson, examine early expressions of Beckford's vision and style through the late 1770s and into the 1780s; all are interesting, but Benyon's first essay, which explores Beckford's homoeroticism in the context of eighteenth-century understandings of sexuality, childhood, identity, and gender, seems particularly timely. Under the heading 'Mature Fiction' appear three further essays which shift the focus of the volume to the last two decades of the eighteenth century; these include essays by John Garrett (addressing Beckford's satiric vision), Didier Girard (on Beckford's command of French style as evinced from manuscript versions of the first Épisode de Vathek), and the volume's editor, Kenneth Graham, which explores the 'uneasy truce' between Enlightenment and Gothic imposed by the peculiar sensibility exhibited throughout the unified narrative of Vathek with The Episodes of Vathek.

The next section of the collection, 'Beckford in Portugal,' is comprised of essays by Laura Bettencourt Pires and Paulo Mugayar Kühl concerning Beckford's travels to Portugal, and his responses to Portugese landscape and culture. The section 'Fonthill Abbey and Bath' is focussed upon Beckford's interest in landscape and interior design, and includes essays by Stephen Clarke, Laurent Châtel, and George Haggerty, all nicely illustrated with reproductions and photographs. The volume concludes with Kevin Cope's essay 'The Millenium Continues to be an Incident: Occasional Reflections on the Renewability of Beckford's Reputation.' Cope's reflections wander freely through Beckford's oeuvre and his reputation, and into contemporary popular culture, and locate his subject's paradoxical appeal in his ahistorical 'incidentalism,' an artistic vision of such disconnectedness that his works seem at once immediately relevant, and at the same time impossible to assimilate to recognized categories. Given the bewildering variety of Beckford's own interests and productions, so well reflected in this volume, it is difficult to disagree.

Those who enjoy a touch of scandal and sordid scenes of low-life in their scholarly reading will undoubtedly be attracted to L. L. Bongie's From Rogue to Everyman: A Foundling's Journey to the Bastille (Montreal: McGill-Queen's University Press, 2004). Bongie's compelling and extensively-researched volume recounts the history of Charles de Julie, a 
rogue of the first order who haunted the seedier quarters of Paris in the mid-eighteenth century. The hero of Bongie's study lived a various life indeed: through his checkered and unsavoury career, de Julie was a soldier (and deserter), a pimp, a pedlar of scandalous news sheets, an informer and police officer, and, most surprisingly, a poet. That his career ended with two years imprisonment in the Bastille, his release from which in July of 1755 preceded his death by only a few months, seems hardly surprising. That the reader should find herself caring about the sad conclusion of this unregenerate life is a great deal more so, and is testament both to Bongie's abilities as a storyteller, and to the unexpected universality of his protagonist's lifelong struggles.

These struggles ended, at last, with de Julie's death in poverty and obscurity: not even Bongie's obviously painstaking research has been able to reveal the exact date or circumstances of his protagonist's demise. We are, however, offered a series of prison letters written by de Julie from the Bastille in the last years of his life. One of the most interesting aspects of these, and indeed, of de Julie's comportment throughout his life, is the absence of any obvious rancour against the system that was, in effect, to kill him in his thirtieth year. This rogue's activities were, as Bongie notes, 'conducted eagerly and complicitly within rather than outside the broader social norms of his times'; he was very much a man of the older, pre-revolutionary world, accepting of the assumptions of the social, political, and economic system that so effectively, and fatally, victimized him.

Bongie offers his reader 'a ground level, unapologetically material sense of everyday low life during one of the most fascinating periods of French history' (ix-x), and this he unquestionably delivers. Our fascination with de Julie notwithstanding, this study is most truly a social history, for its vivid evocations of mid-century Paris, its playhouses, taverns, gardens, and, most of all, its darkly criminal and wretched underworld, provide enormously valuable insights into the day-to-day reality of what was then still, perhaps, Europe's greatest capital city. The same can be said of the innumerable portraits in miniature of the government functionaries, soldiers, police, prostitutes, and criminals that populated this world. Bongie treats de Julie himself as a kind of exemplification of all that was most fascinating, and most horrifying, about the metropolis: the sheer variety of his experiences qualifies him as the 'everyman' of the volume's title, and ensures that the reader connects, and ultimately even empathizes, with this strange antihero of the ancien régime. His was indeed the 'life of a marginal man caught up in a desperate struggle to survive by fair means or foul' (x).

Crime and punishment is also the subject of two fascinating 'companion' titles, published by Thoemmes under the steady guidance of James 
E. Crimmins, that compile eighteenth- and nineteenth-century writings on the death penalty: a reprint (with new introduction) of Basil Montagu's seminal three-volume collection, The Opinions of Different Authors upon the Punishment of Death, which first appeared between 1809 and 1813 (Bristol: Thoemmes Continuum, and Tokyo: Edition Synapse, 2004); and a wide-ranging seven-volume collection of writings by both supporters and opponents of capital punishment, selected and introduced by Professor Crimmins, entitled The Death Penalty: Debates in Britain and the U.S., 1725-1868 (Bristol: Thoemmes Continuum, and Tokyo: Edition Synapse, 2004). One of the most useful features of the Thoemmes reprint of the Opinions is the provision of a 'bibliographic list of contents' that identifies the sources of Montagu's selections, as well as modern standard editions of the texts (where they are available). Crimmins's introduction makes a persuasive case for Montagu's contributions ('as an agitator,' $x v$ ) to penal law reform being given short shrift by historians, and describes the twelve hundred pages (and nearly one hundred items) of the volumes as 'an epic attempt by Montagu to define comprehensively the terms of debate' between advocates and opponents of the death penalty (xx). Like the Opinions, Crimmins's own selection of writing (which takes care not to repeat the contents of the Opinions, and includes complete texts as often as possible) represents both sides of the argument. Approached from a number of perspectives - moral, legal, religious, political, and philosophical - what Crimmins describes as 'the core debates' about the death penalty 'unfolded and took their recognizably modern shape' (xvii) in the eighteenth and early nineteenth centuries. It is difficult not to be struck, as one reads Crimmins's helpful list of the principal issues explored in the materials he has collected, by the extraordinary relevance of these discussions to contemporary debates (especially in the United States).

Professor Crimmins also has written an accessible, informative, and engaging ninety-seven-page introduction to the thought (moral, legal, political, and constitutional) of Jeremy Bentham (1748-1832). Part of the Wadsworth Philosophers Series, On Bentham (Belmont, CA: Wadsworth, 2004) serves its intended audience of undergraduates and interested general readers well: Bentham's utilitarian ethics, the 'unambiguously secular and empiricist conception of the world' upon which utilitarianism is founded, Bentham's critical analysis of British penal law, his political economy, his panopticon plans, and his ideas on constitutional law are all discussed with clarity and precision, and are accompanied with accounts of the current critical debates around each.

That painstaking scholarly archival and documentary work by Canadian scholars is not limited to the fields of law and the social sciences is amply demonstrated by two new works on the subject of music. Musi- 
cologist Paul F. Rice, in his meticulous archival study, Fontainebleau Operas for the Court of Louis XV of France by Jean-Philippe Rameau (16831764) (Lewiston: Edwin Mellen Press, 2004), Volume 107 in the continuing series 'Studies in the History and Interpretation of Music,' focuses on the five operas (the scores for four of which - Daphnis et Églé, Les Sibarites, La Naissance d'Osiris, and Anacréon - survive in some form) that Rameau wrote for performance at the royal residence at Fontainebleau in 1753 and 1754 . The book opens with a fine, fully contextualized chapter on Fontainebleau's performance spaces and practices; court intrigues, personalities (with special attention to the fascinating figure of Rameau's antagonist, Mme de Pompadour), and the role that politics played in the musical life of the court of Louis $\mathrm{XV}$; and the querelle des bouffons (pitting proponents of Italian opera against supporters of the French, with Rameau - the former radical - cast in the role of iconic hero of the French tradition). Throughout his careful, albeit at times necessarily speculative, examination of archival source material, Rice's aim is to create a 'reasonably accurate picture' (239) of the Fontainebleau performances. In addition to determining the likely ordering of the scores, Rice explores the relationship between Rameau's creative, compositional process and the changing configuration of the performance space at Fontainebleau (because of the renovation of the theatre between 1753 and 1754); comments on Rameau's varied and clever orchestration and his 'remarkable' (263) attention to orchestral colour; and describes the composer's brilliance as a musical dramatist who, through his settings, 'reveals his understanding of the psychology of the characters' (144). This timely study of Rameau's late work takes its place among the growing body of scholarship and criticism on the composer - a happy accompaniment to the ongoing publication of the new complete works (under the general editorship of Sylvie Bouissou).

Professor Rice has also been busy making the British music of the period more accessible: his catalogue of eighteenth-century British solo secular cantatas - aimed at scholars, teachers, and performers - is accompanied by a helpful introduction that describes the range of the genre and the changing social role of cantatas in the eighteenth century (from works for home entertainment, played by dedicated amateurs, to complex, increasingly florid works performed by professional singers in public pleasure gardens like Vauxhall and Raneleigh). Each entry in The Solo Cantata in Eighteenth-Century Britain: A Thematic Catalog (Warren, Michigan: Harmonie Park Press, 2003) - Number 84 in the series 'Detroit Studies in Music Bibliography' - provides manuscript sources, published sources (including availability on microfilm), poet's name, a synopsis of the text, musical specifications (each movement is listed by textual incipit, with musical incipits for closed-form airs), secondary 
literature, and discography (although few of these cantatas have been recorded). Detailing works such as 'The Roast Beef Cantata,' and 'Tristram Shandy's Ghost' (described as 'a series of non-sequiturs'), Rice's reference book should be of broad interest, as the repertory it catalogues 'provides the opportunity to assess the cultural and musical changes experienced in England during the century' (xviii).

Turning from music to art, and in particular to the unique marriage of the visual and the verbal in the work of William Blake, it is a pleasure to note the appearance of John B. Pierce's The Wond'rous Art: William Blake and Writing (Madison: Fairleigh Dickinson University Press; London: Associated University Presses, 2003). Characterizing his critical study of 'the representation of writing in the works of William Blake' as 'enabled' by deconstruction, with its 'double writing' and forms of 'undecidability' (160-61), Pierce argues that this approach (the report of the death of which - at least for him - would seem to have been greatly exaggerated) is especially useful in bringing together 'the material Blake and the theoretical Blake' (11). Pierce treats writing from 'three complementary perspectives' (25) throughout this study: as a thematic concern (how Blake depicts the act and instruments of writing - the 'scenes of writing' - in both text and design), as a formal category with conventions different from speech, and as a theoretical construct (as the written mark 'attempts to body forth' some concept, it 'fails to do so. It stands for an absence'). These perspectives allow Pierce to discuss the complexities of Blake's depiction of writing - as at once, for example, acting as a mediator between the human and the divine (the 'wond'rous art of writing' having been given 'to Man' by God), and acting as a constraining, confining, and authoritarian force (the 'textual tyranny' represented by the figure of Urizen 'flanked by stone tablets and crouched on a book of blots while writing and engraving in books on either side of his tremendously compacted body'[59]). One cannot, of course, 'summarize' deconstructive readings. One can, however, ask whether a statement like the following, which appears at the conclusion of Pierce's chapter on the Continental Prophecies, is persuasive: 'Even as Blake writes the work into a longer linear narrative that appears directed toward culmination, completion, and apocalypse, he writes the text into resistance, rupture, and fragmentation' (89-90). For this reader, it is.

The work of eighteenth-century scholars in Canada is marked by a healthy balance between traditional scholarly projects like editing, cataloguing, and archival study, and richly interdisciplinary and innovative studies of eighteenth-century culture that engage gender and sexuality studies, scientific and philosophical contexts, legal history, political theory, and creative expression in all its forms. If the diverse and exciting studies of the eighteenth century sampled in this brief overview are any 
244 Mark McDayter \& Lisa Zeitz

indication, the future of Canadian scholarship on that most vibrant and fascinating of periods will be seen to be very bright indeed.

MARK MCDAYTER \& LISA ZEITZ

University of Western Ontario 